\title{
$\begin{array}{r}\text { WAgENINGEN } \\ \text { UNIVERSITY \& RESEARCH } \\ \hline\end{array}$
}

\section{Usefulness of an opportunistic data analysis approach to evaluate if environmental regulations aim at relevant applications}

Corradini, F., González, N., Casado, F., Rojas, V., \& van der Ploeg, M.

This is a "Post-Print" accepted manuscript, which has been published in "Geoderma"

This version is distributed under a non-commercial no derivatives Creative Commons (c) $(\Theta \Theta \Theta$ (CC-BY-NC-ND) user license, which permits use, distribution, and reproduction in any medium, provided the original work is properly cited and not used for commercial purposes. Further, the restriction applies that if you remix, transform, or build upon the material, you may not distribute the modified material.

Please cite this publication as follows:

Corradini, F., González, N., Casado, F., Rojas, V., \& van der Ploeg, M. (2019). Usefulness of an opportunistic data analysis approach to evaluate if environmental regulations aim at relevant applications. Geoderma, 351, 261-269.

https://doi.org/10.1016/j.geoderma.2019.05.007 


\section{ENVIRONMENTAL REGULATIONS AIM AT RELEVANT APPLICATIONS}

3

4 Fabio Corradini ${ }^{1,2}$ • Natalia González ${ }^{3} \cdot$ Francisco Casado $^{2} \cdot$ Verónica Rojas $^{2} \cdot$ Martine van der $^{2}$ $5 \quad$ Ploeg $^{1}$

6

$7 \quad{ }^{1}$ Soil Physics and Land Management Group, Wageningen University \& Research, 6708PB

8 Wageningen, The Netherlands

$9 \quad{ }^{2}$ Instituto de Investigaciones Agropecuarias, INIA La Platina. Casilla 439, Correo 3, Santiago, Chile

10 3Servicio Agrícola y Ganadero, SAG Dirección Regional Metropolitana. Paseo Bulnes 140,

11 Santiago, Chile

12

$13 \bowtie$ Fabio Corradini

14 fabio.corradini@inia.cl

$15 \quad$ Tel: +56 225779275

16 


\section{Abstract}

Environmental regulations aim to protect the environment from anthropogenic detrimental effects. To ensure their effectivity and to avoid unexpected results and budget losses, environmental regulations need careful designs grounded in observational data. Comprehensive monitoring campaigns are not always achievable in developing economies, since environmental monitoring is not always prioritized due to resource constraints. We propose to tackle the problem using an opportunistic data analysis approach as supplementary information for environmental monitoring. We applied this approach to evaluate the application of Chilean phosphorus $(P)$ fertilization subsidy. A risk assessment for $\mathrm{P}$ surplus was performed using three datasets: (1) secondary data acquired from thousands of unclassified laboratory records from the private sector $(n=7,957)$; a dataset of soil available $\mathrm{P}$ from a budged-restricted monitoring campaign, and; (3) a conjoint dataset that comprises 1 and 2. Results indicate that while laboratory records represented the general characteristics of the study area, field monitoring data evidenced a surplus of soil P. Using the laboratory records to enrich the data acquired by field monitoring modified the reality reflected by the monitoring data alone. The use of the conjoint dataset leads to the conclusion that soils in the study area had enough available $P$ for optimum production, and that farmers were already using external sources of $P$ fertilizers within the current market structure. Our study constitutes an example of the use of private data to contribute to public soil monitoring programs and environmental regulation designs. The case study serves as a successful example of opportunistic data usage in environmental monitoring, as a low-cost alternative to complement field observations.

\section{Keywords}

40 Opportunistic data $\cdot$ Soil monitoring $\cdot$ Phosphorus surplus $・$ Chilean soils Environmental 41 regulation 


\section{Introduction}

44 Environmental regulation is important as it protects the environment from the detrimental effects of human activities, aiming at population safety (Sullivan et al., 2018). As part of the task of environmental regulation, subsidies in agriculture target social protection from deprivation and scarcity, environmental sustainability, and improved productivity (Tirivayi et al., 2016). In developing economies public expenditures mostly focus on the productive sector, where a larger fraction of the total budget is used in agriculture (Yu et al., 2015). Social protection and agriculture become interrelated processes, demanding limited resources that are not always available (Fiszbein et al., 2014; Lowder et al., 2017).

Agricultural subsidies are often oriented toward conservation practices to avoid environmental detriments. While ecosystem protection and restoration has been embraced by the international community through the United Nations Sustainable Development Goals, farmers could be reluctant to use environmental-favourable land managements (Floress et al., 2018). This has caused the implementation of top-down policies where farmers adopt new practices when direct rewards, such as subsidies, are in sight (Tarfasa et al., 2018). As in this way subsidies can become the goal of the practice, the end result is usually undermined, with studies showing farmers doing the bare minimum to get the subsidies going (Auerswald et al., 2018). Therefore, agricultural subsidies need careful designs and evaluations to avoid unexpected results and budget losses (Mason et al., 2013; Nyssen et al., 2017).

Nutrient depletion constitutes a symptom of land degradation, therefore subsides for fertilizer acquisition could be intended as compatible with conservation practices (Koppmair et al., 2017). Fertilizers subsidies are relevant in developing economies where a negative feedback describes the relation between low soil fertility and poverty (Barrett and Bevis, 2015). Although it is an attractive measure for policy makers in growing economies, giving subsidies for fertilizer applications has detractors reporting numerous cases of failure (Holden and Lunduka, 2014; Mason and Jayne, 2013; Nyssen et al., 2017). When applied within a frame of additional interventions that increase soil fertility, subsidizing fertilizers applications presents a tempting solution for limited public budget since two problems, poverty and land degradation, are tackled at the same time (Ricker-Gilbert and Jayne, 2017). 
Designing relevant fertilizer subsidy programs should consider the current status of soil fertility. While poor soil fertility may lead to poverty, fertilization excess poses a threat to environmental health (Dupas et al., 2015; Fischer et al., 2017; Watson et al., 2007). Monitoring the status of soil fertility could be covered by extensive monitoring programs, but these demand resources that are often not foreseen in research budgets. Yet, data availability can be broadened if alternative data sources are used in an opportunistic data analysis approach. The opportunistic approach refers to the use of any data that have been collected without standardized protocols (opportunistic data), having incomplete observations or absent accompanying data, but which may, nonetheless, constitute a research prospect (Silvertown, 2009). Although the lack of metadata usually makes opportunistic data unreliable, when these alternative data sources are coupled with data gathered under proper scientific aims, the opportunistic data approach reduce research costs, and can improve monitoring results (Giraud et al., 2016).

Although the use of an opportunistic data approach is increasing in ecology and environmental monitoring (Abbott et al., 2018; Lots et al., 2017), it has not been used for evaluating the relevance of environmental regulations. Therefore, we investigated if an opportunistic data approach can be used to assess the relevance of environmental regulations, using opportunistic data as low-cost ancillary information in factual monitoring campaigns. To test the idea a Chilean case study is provided. Chile presents an agricultural subsidy regulation completely oriented to soil conservation practices (Ministerio de Agricultura, 2010), including subsidies to fertilization practices, with the scope of promoting integral management plans that prevent soil erosion. The aim of this paper is to test if an opportunistic data approach is useful to evaluate the application relevance of a phosphorus $(\mathrm{P})$ fertilization subsidy from the Chilean government. We will do so using three datasets with different structural characteristics to determine the soil P status. The first dataset comprises the records for soil available $\mathrm{P}$ of a regional soil laboratory, standing as opportunistic data as it does not include accompanying information. The second dataset includes soil P data from a time-restricted monitoring campaign (factual monitoring data), and the third conjoins both. 


\section{Material and methods}

102

103

104

105

106

107

108

109

110

\subsection{Study area}

The study took place in the Chilean Metropolitana Region, an area of $15,400 \mathrm{~km}^{2}$ located in the north of the Chilean Central Valley. As this region is located between the Andean and the Coastal mountain ranges only $2,770 \mathrm{~km}^{2}$, less than $20 \%$, of the surface corresponds to agricultural fields. The study area included arable soils and forage prairies of moderate slopes where commercial agriculture is performed, comprising a total area of $2,273 \mathrm{~km}^{2}$ (Fig. 1 Interactive map). Natural grazing prairies and marginal soils ( $<75 \mathrm{~cm}$ depth, stoniness $>30 \%$, and slope $>5 \%$ ) were excluded.

The climate according to Köppen-Geiger climate classification is warm temperate with warm summers and low precipitation (Csb) (Kottek et al., 2006). There is, however, a transition to an arid climate (BSk) towards the North of the valley. Mean annual precipitation is about $300 \mathrm{~mm}$, and the average annual temperature is $15{ }^{\circ} \mathrm{C}$, with $23^{\circ} \mathrm{C}$ maxima and $10{ }^{\circ} \mathrm{C}$ minima (Dirección Meteorológica de Chile, 2010-2016). The climate dictates that the soils within the study area present a xeric moisture regime and a thermic temperature regime (CIREN, 1996). There are five soil orders within the study area, from which Mollisol predominates encompassing $70 \%$ of the total area. Other soil orders are Alfisols (11\%), Inceptisols (13\%), Entisols (2\%), and Vertisols (4\%). Soil suborders, great groups, and subgroups are indicated in the Interactive Map (Fig. 1) and the area of each is shown in the supplementary material (S1).

\subsection{Environmental regulation: the $\mathrm{P}$ subsidy}

The Chilean soil restoration program was originated when the country joined the MERCOSUR in the $90 \mathrm{~s}$. At that time, there was pressure from the productive sector to include measures that targeted both production and restoration. It was expected that the elimination of customs duties and tariff restrictions on the circulation of goods would affect local production. Therefore, while the main aim of the program was to protect soil from degradation, policymakers had to include subsidies to protect and support national agricultural activities (Caro et al., 2006). The duality of the program aim stands out in the official definition of degraded soil: 'Soils that due to lack of phosphorus, excess acidity, levels of erosion, deterioration of vegetation cover or to other physical, 
chemical or structural limitations for their occupation, cannot be used efficiently in a sustainable way in agricultural production' (Ministerio de Agricultura, 1999).

Nowadays, the soil restoration program allows farmers to decide freely on the managements for which they want funds for by choosing through a given list of possibilities (see the supplementary material for the complete list S2). There are two elements that stand out from the list. First, the application of fertilizers is included within soil restoration practices, which reflects back to the double goal of the policy. Second, P applications are placed in a different cluster than the application of other chemical elements (K, Ca, and $\mathrm{S})$.

Before its implementation at national level, the program was meant for the southern part of the country, where livestock activities take place on Andisols where $P$ is easily fixed (Casanova et al., 2013). The original practices were bounded to this original intention. Later, when the program was extended to the whole country, it was reviewed by a joint committee. The committee included representatives of the productive sector and government productive development organizations. Additional practices were included, but none of the first was omitted. As a result, the P subsidy was kept within the list of fundable practices. Through the program, the government subsidizes phosphorus (P) applications when soil available $\mathrm{P}$ drops below $20 \mathrm{mg} \mathrm{kg}^{-1}$ (based on the Olsen method). This work was framed within the aim of the government to avoid a P deficit scenario, thus the $20 \mathrm{mg} \mathrm{P}$-Olsen $\mathrm{kg}^{-1}$ were used as a threshold in a risk assessment approach.

\subsection{Opportunistic dataset}

Through their Soil and Plant Nutrition Laboratory located in the La Platina Regional Research Centre, the Agricultural Research Institute (INIA) provides analytical services to both farmers and researchers/scientists from the Chilean Central Valley. Rarely, clients corresponds to small farmers, being the service required mostly by big producers ( $>20 \mathrm{ha}$ ), governmental institutions, and researchers. The customer profile implies that generally the location of the sites where the samples are taken is not reported. Clients usually present only a commercial address in the capital for sending the results when ready. Small producers send samples for analysis only when they are motivated by operators of governmental agricultural extension programs, who act as mediators darkening once again the provenience of soil samples. In this way, farmers that do not present 
adequate soil management practices -among who the government should promote practices to avoid environmental detriments- are possibly underrepresented.

Analytical reports from 2005 to 2015 were coerced into a single dataset (INIA dataset). The database built constitutes opportunistic data as the records that it contains were not collected aiming at monitoring soil nutrient status at any particular scale. The INIA dataset holds observations of soil chemical properties from samples that were taken in unknown locations of the country Central Valley without standardized protocols or sampling designs, and that may or may not have being part of research. Therefore, the dataset is characterized by a complete lack of accompanying geographical data, including for each entry only a vague temporal reference of when (year) the soil analysis were performed (not when the samples were collected).

\subsection{Soil monitoring dataset}

\subsubsection{Data collection}

Sampling points were distributed within the study area using a conditioned Latin hypercube sampling (cLHS) algorithm, which proposes to stratify sampling according to exhaustive ancillary data (Minasny and McBratney, 2006). The algorithm provides a full coverage of the range of each variable, assuring representativeness of the underlying information. To this purpose, the $R$ package 'clhs' (conditional Latin hypercube sampling) was used (Roudier, 2017; Roudier et al., 2012). The accompanying data used to condition the sampling locations were elevation (The National Aeronautics and Space Administration and Ministry of Economy Trade and Industry, 2011), land use (CONAF and CIREN, 2013), and soil orders and aptitude for agricultural use provided by Chilean soil survey maps (CIREN, 1996). The aptitude for agricultural use is a local index given in Chilean soil survey maps to identify the overall capability of a given soil series for crop production. They aggregate the information of soil depth, slope, drainage, texture, and abundance of rock fragments (as texture modifiers), and are described by CIREN (1996). A total of 484 sampling locations were distributed along the study area. The distribution of the sampling locations by soil order, suborder, great group, and subgroup is shown in the supplementary material (S1). 
Samples were collected between the third week of November and the last of December 2016. The time of the year corresponds with the growing season, thus fertilization and irrigation programs are in operation. The sample locations determined by cLHS algorithm were checked and modified as needed at the time of sampling. Sampling under unrepresentative conditions (points near field borders, drains, livestock shelters, etc.) was avoided, modifying pre-locations accordingly. Every sampling point was georeferenced. Each sample was composed of three subsamples taken $5 \mathrm{~m}$ apart from its sampling point, at the vertices of an equilateral triangle, being the georeferenced location the barycentre. Similar sampling procedures are reported by Kelepertzis (2014). Subsamples were taken with a shovel from the topsoil (0 to $20 \mathrm{~cm}$ depth) and homogenized in plastic pails. Composite samples of $1 \mathrm{~kg}$ were extracted from the pails, stored in plastic bags, and transported to the Soil and Plant Nutrition Laboratory at INIA, for further analysis.

\subsubsection{Soil samples analysis}

Soil samples were dried in a forced air oven at $40 \pm 5{ }^{\circ} \mathrm{C}$ until they reached a constant weight (model 1390FX, Sheldon Manufacturing). Dried samples were sieved at $2 \mathrm{~mm}$ and stored in plastic flasks. Every sample was analysed for available P and P buffer capacity.

Soils in this section of Chilean Central valley are neutral to alkaline and might present $\mathrm{CaCO}_{3}$ (Casanova et al., 2013; CIREN, 1996), thus soil testing for available $P$ was determined $\left(\mathrm{mg} \mathrm{kg}^{-1}\right)$ using the Olsen method (P-Olsen) (Olsen et al., 1954) as described by Sadzawka et al. (2006). Chilean standard laboratory procedures propose a chemical analysis to quantify $\mathrm{P}$ fixation, known as soil P buffer capacity (P-Buffer). The method consists of incubating soil at $60{ }^{\circ} \mathrm{C}$ for 24 hours with and without addition of $\mathrm{P}\left(200 \mathrm{mg} \mathrm{kg}^{-1}\right)$ to then quantify available $\mathrm{P}$ by the Olsen extraction. The difference in available $P$ between the sample treatments (with and without $P$ addition) are then used to estimate soil $\mathrm{P}$ fixation. Results are reported as the amount of $\mathrm{P}(\mathrm{kg})$ needed to increase one unit of P-Olsen $\left(\mathrm{mg} \mathrm{kg}^{-1}\right)$ in one hectare of soil, considering a sampling depth of $20 \mathrm{~cm}$ (Sadzawka et al. 2006). To our knowledge the method has had only a regional use, and is nowadays used in Chile to make fertilizer dose recommendations to farmers.

\subsubsection{Quality control}


Soil samples from Wageningen Evaluating programs for Analytical Laboratories (WEPAL) were used as reference material to check P-Olsen determination accuracy. WEPAL provide soil samples which chemical composition has been retrieved from analytical results provided by several laboratories around the world. Every laboratory uses similar determination procedures, sample preparation, and technical equipment. As a criteria, results from reference samples were within one standard deviation of the reported WEPAL value. Furthermore, $20 \%$ of samples were analysed in duplicate seeking less than $10 \%$ variation, according to the inherent repeatability of the method reported by Sadzawka et al. (2006).

All reagents used were analytical grade and were obtained from Merck KGaA. The sulphuric acid used in the preparation of the molybdenum blue solution was ultrapure quality. The calibration standards of $\mathrm{P}$ were prepared by appropriately diluting stock solutions of $1000 \mathrm{mg} \mathrm{L}^{-1}$. The activated charcoal used during the filtration process was treated to get a blank absorbance less than 0.015 units. All solutions were prepared with ultrapure water from a nanopure system (Barnstead E-Pure D4642, Thermo Fisher). All glassware and polyethylene bottles were cleaned by soaking in a $10 \%(\mathrm{v} / \mathrm{v}) \mathrm{HNO}_{3}$ solution followed by three rinses with deionized water.

\subsection{Statistical analysis}

\subsubsection{Opportunistic dataset}

234 The INIA dataset did not contain P-Buffer records, thus only P-Olsen was analysed. Descriptive 235 statistics for the data entries of P-Olsen within INIA dataset were generated (mean, median, variance, and quantiles). Data were log-transformed and its normality tested by Shapiro-Wilk normality test. As log-transformed data showed a good approximation to a normal distribution, a normal distribution was parametrized by bootstrapping the mean and standard deviation from INIA dataset entries. One thousand sub-samples of 100 data entries were generated to estimate each 240 statistical parameter. Descriptive statistics were calculated for the mean $(\mu)$ and the precision $(\tau=$ $\left.2411 / \sigma^{2}\right)$. Shapiro-Wilk test was used to test the normality of the simulated $\mu$ values, while a gamma 242 distribution was fitted by maximum likelihood estimation (MLE) to т. The probability for a random observation to be above the $20 \mathrm{mg}$ P-Olsen $\mathrm{kg}^{-1}$ was assessed by a Monte Carlo approach, 
sampling random values of $\mu$ and $\mathrm{T}$ from their probability functions. The Monte Carlo simulation was used to generate 1000 possible scenarios that were summarized using descriptive statistics.

\subsubsection{Soil monitoring dataset}

Soil field data were analysed according to frequentist procedures. Descriptive statistics for P-Olsen concentrations were calculated. Concentrations were log-transformed, and the normality of the data tested by Shapiro-Wilk. As P-Olsen concentrations were log-normally distributed, their mean and standard deviation calculated as part of the descriptive statistics were used to estimate the

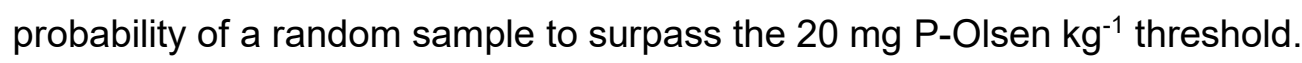

P-Buffer did not show a known pattern, therefore, an empirical cumulative distribution function (ECDF) of its expected values was calculated. An empirical cumulative distribution function ranks the empirical observations assigning a cumulative probability to each observation equal to the fraction of observations till its ranked position. The median, mean and quantiles were calculated for P-Buffer to characterize its statistical dispersion.

As available $\mathrm{P}$ and $\mathrm{P}$ saturation are known to be related (Allen and Mallarino, 2006; Fischer et al., 2017), the correlation between P-Olsen and P-Buffer was tested using the Pearson correlation coefficient $(r)$.

To evaluate the influence of different soil conditions over P-Olsen concentration north-south and east-west spatial transects were plotted to address its spatial distribution. In this evaluation, land use was used as a factor, and block means were added every $3 \mathrm{~km}$.

\subsubsection{Conjoint dataset}

Bayesian statistics take into account prior knowledge or beliefs about a phenomenon to update that knowledge using new data (a posterior knowledge, simply called posterior). We used this approach to integrate the opportunistic data with the field data. To this goal, the INIA dataset was used to define a prior belief of soil P status within the study area, to then update the belief using the soil monitoring dataset as new information. We will refer to this procedure from now on as an opportunistic data analysis approach since the data from the factual monitoring campaign is 
analysed under the light of the opportunistic dataset. As mention in section 2.6.1 the approach was used only for P-Olsen, since there were no entries for P-Buffer in the INIA dataset to define a prior. To obtain the posterior distribution, a likelihood function that relates the prior parameters to the studied phenomenon has to be established before calculations. The posterior distribution is then the product of the prior distribution and the likelihood function. In this study, the likelihood function and its parameters were defined analysing the entries from the INIA database. As pointed in section 2.6.1, in central Chile soil (log-transformed) P-Olsen is normally distributed. Therefore, the conditional distribution of the field data $(y)$, given the mean $(\mu)$ and precision $(\tau)$ parameters, is $p(y$ | $\mu, T)=N(\mu, 1 / T)$. Estimating the parameters of a normal distribution using Bayesian inference and conjugated priors is a common approach (see Gelman et al. (2013) for a complete explanation). Here, the use of a conjugate prior presents the advantage that the posterior distribution (i.e. the parametrised normal distribution) has a known form (the same as the prior), making the parameter estimation a deterministic process.

As the mean $(\mu)$ and precision $(\mathrm{T})$ of the proposed normal distribution are unknown, the corresponding conjugated prior is the Normal-Gamma distribution that has the form $p\left(\mu, \tau \mid \mu_{0}, k_{0}\right.$, $\left.\alpha_{0}, \beta_{0}\right)=N\left(\mu \mid \mu_{0},\left(k_{0} T\right)^{-1}\right) G a\left(T \mid \alpha_{0}, \beta_{0}\right)$. In this prior distribution, the mean $(\mu)$ and precision $(T)$ parameters of the normally distributed observations are drawn respectively from a normal distribution with mean $\mu_{0}$ and variance $\left(k_{0} t\right)^{-1}$, and from a gamma distribution with shape $\alpha_{0}$ and rate $\beta_{0}$ which defines $\mathrm{r}$. The $\mathrm{k}_{0}$ parameter is the equivalent sample size of the prior distribution (i.e. $\left.\operatorname{var}(\mu \mid \tau)=1 /\left(\mathrm{K}_{0} \mathrm{~T}\right)\right)$, and represents the prior belief about $\mu$.

With both prior distribution and likelihood defined, random samples from the posterior distribution were drawn using the field data. By this means, different scenarios of soil P status were generated for the study area (random values of $\mu$ and $\mathrm{T}$ ) to compute the probability of having concentrations greater than $20 \mathrm{mg} \mathrm{kg}^{-1}$. The scenarios drawn were summarized by descriptive statistics (median, mean, and quantiles).

To check whether soil orders have differences in P-Olsen, the monitoring dataset was split in two, having Mollisols and other soil orders as the two levels. Sampling from the data subsets, two new posteriors were defined using the same prior distribution and likelihood function defined previously with the opportunistic dataset. Differences between the posteriors were evaluated by 1,000 random 
throws as $T=p\left(\mu_{\text {mollisols }}>\mu_{\text {other orthers }}\right)$, were an average $T$ value approximating 0.5 mean low

differences between factors, and $\mu_{\text {mollisols }}$ and $\mu_{\text {other orders }}$ stand for the posterior mean of the different soil orders. As the data were unbalanced, the subset of Mollisols $(n=306)$ was resampled to match the quantity of observations of the other soil orders $(n=178)$. The process of resampling and testing the means was repeated 1,000 times. The results of the 1,000 replications of the $\mathrm{p}\left(\mu_{\text {mollisols }}>\mu_{\text {other orthers }}\right)$ test was summarized using descriptive statistics.

\subsubsection{Statistical software}

Statistical analysis were performed in the $R$ environment (R Core Team, 2017). The packages 'raster' (Hijmans, 2017) and 'rgdal' (Bivand et al., 2017) were used in combination with QGIS

312 (Venables and Ripley, 2002) was used to perform MLE estimations when needed.

\section{Results}

3.1 Opportunistic data

The INIA dataset had 7,957 entries for P-Olsen, and zero for P-Buffer. Although data of P-Olsen concentrations present a slight right skewness when centred, scaled and log-transformed, a lognormal distribution explains with sufficiency the expected values for P-Olsen. Figure 2 presents the histogram for P-Olsen values within INIA database, and the density of a normal distribution. Consequently, P-Olsen concentrations were log-transformed (In) in further calculations. Normal distributions are characterised by two parameters, the mean $(\mu)$ and the precision $(\tau)$, that can be drawn by bootstrapping from the INIA database observations. The bootstrapped values are used to define each parameter ( $\mu$ and $\mathrm{T}$ ) expected distribution. Table 1 presents descriptive statistics for the bootstrapped $\mu$ and $\mathrm{T}$ and Fig. 3 shows their histograms and theoretical distribution densities. The mean concentration was normally distributed (Shapiro-Wilk $p$-value $=0.517)$ as $p(\mu$ | $\left.\mu_{m}, \sigma_{m}^{2}\right)=N\left(\mu_{m}=3.09, \sigma_{m}^{2}=0.015\right)$, where $\mu$ stands for a random observation of the sample mean given $\mu_{m}$ and $\sigma_{m}^{2}$ as mean and variance parameters of a normal distribution $(N)$. Similarly, the precision $\mathrm{\tau}\left(1 / \sigma^{2}\right)$ for P-Olsen concentration followed the gamma distribution as $p(\tau \mid \alpha, \beta)=G a(\alpha=$ 
and rate parameters of the gamma distribution $(\mathrm{Ga})$. Having the probability distributions defined for both $\mu$ and $\mathrm{T}$, the probability of surpassing the P-Olsen concentration threshold of $20 \mathrm{mg} \mathrm{kg}^{-1}$ $(\ln (20)=2.99)$ was $53 \%$.

\subsection{Soil monitoring}

Similarly, the measurements of P-Olsen concentration for the field data can be represented by a log-normal distribution (Fig. 2). The observed mean and precision were higher than that showed by the INIA dataset, indicating that P-Olsen concentrations are expected to be higher without presenting a large variation (Table 1). Moreover, the probability of surpassing the P-Olsen threshold of $20 \mathrm{mg} \mathrm{kg}^{-1}$ was higher than that of the opportunistic data, rising up to nearly $80 \%$ of chances $(17 \%$ increase $)$.

The observed mean for P-Buffer was $6.6 \mathrm{~kg} \mathrm{P} \mathrm{ha}^{-1}$, with a standard deviation of $6.7 \mathrm{~kg} \mathrm{P} \mathrm{ha}^{-1}$. The distribution of observations did not approached a normal distribution, even when the data were logtransformed. The gamma distribution also failed to represent the field observations. Therefore, a better characterization of the observed values is given by measures of statistical dispersion different than $\mu$ and $\mathrm{T}$. The field data presented a median of $5.4 \mathrm{~kg} \mathrm{P} \mathrm{ha}^{-1}$, an interquartile range of $1.9 \mathrm{~kg} \mathrm{P} \mathrm{ha}^{-1}$, and a $95 \% \mathrm{Cl}$ that ranged between 2.5 and $19.5 \mathrm{~kg} \mathrm{P} \mathrm{ha}^{-1}$ (Table 1). The ECDF function was estimated to calculate expected probabilities for a given P-Buffer value (Fig. 4). There was not a significant correlation between P-Olsen concentrations and P-Buffer $(r=0.23)$.

Regarding the spatial distribution of the studied variables, both P-Olsen and P-Buffer did not presented a clear spatial pattern. Figure 5 present the distribution of P-Olsen concentration within the studied area including general east/south transects. Observations were commonly above the $20 \mathrm{mg} \mathrm{kg}^{-1}$ threshold and presented a slight increase towards the south.

\subsection{Opportunistic data analysis approach: Expected P-Olsen}

The $p\left(P\right.$-Olsen $\left.>20 \mathrm{mg} \mathrm{kg}^{-1}\right)=0.53$ that the INIA dataset presents is no more than a guess of $p(P$ Olsen > 20) for the Chilean Central Valley. The sampling campaign was focused within the study area, and corresponds to 484 sampling points, which suggest that $p\left(P\right.$-Olsen $\left.>20 \mathrm{mg} \mathrm{kg}^{-1}\right)=0.79$. As it could be argued that it is a small dataset, we explore an alternative (opportunistic approach) 
to conjoin the two. The conjunction procedure take the general guess for the whole Central Valley and focus it within the study area. Which is where the subsidy is meant to be applied.

The values of the prior parameters $\left(\mu_{0}, \alpha_{0}\right.$, and $\left.\beta_{0}\right)$ were calculated using the INIA database, resulting $\mu_{0}=3.09, \alpha_{0}=29$, and $\beta_{0}=46$ (see section 3.1). The $k_{0}$ parameter was estimated using the relation $\mathrm{k}_{0}=\left(\sigma^{2} \mathrm{~T}\right)^{-1}=105$, where $\sigma^{2}=\sigma_{\mathrm{m}}{ }^{2}=0.015$, and $\mathrm{T}=0.63$, which is the expected mean for the prior gamma distribution defined for the precision of P-Olsen concentrations (in a gamma distribution $E[x]=\alpha / \beta$, which in this case is $29 / 46=0.63)$.

As mentioned, when using a conjugate prior distribution the derived posterior distribution takes the same form, which corresponds to the Normal-Gamma distribution $p(\mu, T \mid y)=N\left(\mu \mid \mu_{n},\left(k_{n} T\right)^{-1}\right) G a(T$ $\left.\mid \alpha_{n}, \beta_{n}\right)$. Here the mean $(\mu)$ and precision ( $\mathrm{T}$ ) parameters of the normally distributed observations given the field data $(\mathrm{y})$, are drawn respectively from a normal distribution with mean $\mu_{\mathrm{n}}$ and variance $\left(k_{n} T\right)^{-1}$, and form a gamma distribution with shape $\alpha_{n}$ and rate $\beta_{n}$. Using the prior parameters from the INIA database and the field data, the posterior distribution parameters $\mu_{\mathrm{n}}, \mathrm{k}_{\mathrm{n}}$, $\alpha_{n}$, and $\beta_{n}$, can be calculated as

$\mu_{n}=\left(k_{0} \mu_{0}+n \bar{x}\right) /\left(k_{0}+n\right)$

$k_{n}=k_{0}+n$

$\alpha_{n}=\alpha_{0}+n / 2$

$\beta_{n}=\beta_{0}+\frac{1}{2} \sum_{i=1}^{n}\left(x_{i}-\bar{x}\right)^{2}+\frac{k_{0} n\left(\bar{x}-\mu_{0}\right)^{2}}{2\left(k_{0}+n\right)}$

Where $\mathrm{n}$ is the data size, and $\bar{x}$ and $x_{i}$ the average and i observation of the field data, respectively. By this, the obtained posterior distribution parameters were $\mu_{n}=3.61, k_{n}=589, \alpha_{n}=271, \beta_{n}=260$. As the estimated parameters $\mu$ and $\mathrm{T}$ are drawn from a probability distribution (Normal-Gamma), they have a range of probable values. Table 1 presents the mean, median and quantiles for $\mu$ and T. Sampling from the posterior distribution random values for $\mu$ and $\mathrm{T}$, an average cumulative distribution function (CDF) with a 95\% confidence interval was estimated for P-Olsen expected concentration within the study area (Fig. 6). The average probability of having a random soil sample presenting a P-Olsen concentration above $20 \mathrm{mg} \mathrm{kg}^{-1}$ was $0.73(\mathrm{Cl}=0.70-0.76)$ according to the estimated CDF. 
There were no differences of P-Olsen between Mollisols and other soil orders. The $\mathrm{p}\left(\mu_{\text {mollisols }}>\right.$ $\mu_{\text {other orthers }}$ ) was equal to $0.56 \pm 0.12$, with a $95 \%$ interval of $0.31-0.77$.

\section{Discussion}

4.1 Using an opportunistic data analysis approach in environmental monitoring

The use of opportunistic data to enrich field monitoring modifies the reality reflected by field data alone. This is expected in Bayesian inference when informative priors are used (Cowles, 2013). To begin with, changes in the results comprised an increase of the uncertainty in the estimations, including it in the output and therefore aggregating new possible interpretations to data (Krueger, 2017). This extra noise is expected since opportunistic data have limited explanatory variables. Secondly, it is important to stress that changes in results are not due to the different statistical approaches followed. Bayesian and frequentists data analysis approaches are both expected to converge when uninformative priors are used -as if in the study case opportunistic data would not have been included (Cowles, 2013). Therefore the changes are an exclusive product of the coupling of soil monitoring data with opportunistic data.

Differences between reliable and opportunistic data have been interpreted before in scientific literature as a positive result (Giraud et al., 2016). In fact, the differences validates the use of opportunistic data as supplementary information (Lima et al., 2017). The enhancement in the output interpretations can be unveiled when the spatio-temporal characteristics of the datasets comprised in the case study are analysed. The INIA dataset has no explanatory variables, which is known to complicate the drawing of probable causes in observational studies (e.g. Lots et al., 2017). In this way, the INIA database only gathers general information through time within the study area. Information that might or might not comprise all soil types, land uses, and land managements within the basin. While for the study case soil samples present a known location in 410 space, they were collected at one given moment in time and under limited land use scenarios. The 411 soil monitoring data neglect, therefore, the general soil $\mathrm{P}$ status of the basin and the changes that it can present through time. To summarize, the INIA dataset expanded the possibilities of the field dataset, including background information of soil types and land uses that would otherwise be 
absent. Conversely, using only the INIA dataset for statistical inference would overlooked the main recipients of the intended subsidy (farmers).

While the use of opportunistic data analysis within the context of environmental monitoring is not new, this is a new insight for soil monitoring. During the last years, with the increase of communication technologies and internet access researches have shown a renewed interest for opportunistic data (Silvertown, 2009). This information source have been mostly used in ecological sciences, where citizen science programs are the most recognizable face (Giraud et al., 2016; Tulloch et al., 2013). Although volunteers base science have also shown good results in environmental monitoring programs (Abbott et al., 2018; Lots et al., 2017), unsteady contribution can jeopardize the results especially when monitoring is only sustained by opportunistic data

424 (Diner et al., 2018). Using information from public and private institutions that gather it from services provision, could be a steady alternative.

The use of Bayesian inference in environmental monitoring where data availability is restricted or has low-resolution has been useful in hydrological studies (Krueger, 2017). When information gathering is a limitation for hydrological monitoring purposes, assessing the uncertainty in estimating environmental variables is a desirable output (Lima et al., 2017). Whereas some studies restrict the data inputs only to trustworthy sources, others enrich the analysis with second data sources or opportunistic data (Abbott et al., 2018). Is the conjunction of opportunistic data and data with knowing sampling efforts (or locations in this case) which confer strength to the monitoring outputs (Giraud et al., 2016). Our study exemplifies this strengthening.

The soil monitoring dataset stands for a particular sampling time during the growing season, when fertilizers are being actively applied. However, within the study area there are several different agricultural schemes such as winter crops, cover crops, fallow systems, threes (deciduous and perennial), and so forth. As a growing season is a mere concept at a regional scale, a sampling designed to include all management scenarios will be forced to address a time component, which means a permanent monitoring effort. As extensive monitoring programs demands resources that are often not foreseen in the governmental research budgets of developing economies, there is a limitation for this methodology. The opportunistic data analysis approach allows interpreting the soil monitoring dataset, as it encompasses a time component (i.e. the laboratory records). 
Correspondingly, the approach allows to evaluate the steady condition reported by the INIA dataset when the agricultural practices are performed by the intended recipients of the subsidy.

\subsection{Effectivity of a P fertilization subsidy: the case study}

The opportunistic data analysis approach suggest that within the study area there is enough soil available phosphorus, therefore the subsidy seems unnecessary for nearly three quarters of the soils. This implies that resources could be spent in other, more critical, necessities. As the subsidy threshold of $20 \mathrm{mg} \mathrm{kg}^{-1}$ was set by a technical committee according to plant responses to $\mathrm{P}$ applications in the Chilean Central Valley (Ministerio de Agricultura, 2015), not only the subsidy is unnecessary but any additional soil P applications.

Phosphorus surplus is also supported by the spatial distribution of P-Olsen of soil monitoring data and by the lack of differences between soil orders. Along the study area different parent materials, climatic conditions, and soil orders are present (Casanova et al., 2013), which were not conditioning the observations. As soil orders should condition P availability (Daly et al., 2015), the P fertilizer surplus hypothesis seems plausible.

The implication of the findings are double. On one hand, the subsidy is not needed because of the P surplus that affects the study area. On the other, results suggests that farmers apply $P$ fertilizers as part of their agricultural management practices, being they behave independent of the subsidy application. Therefore, the subsidy is doubly unnecessary, since there is no management practice that needs stimulation nor productivity gain. On the contrary, high levels of soil P represent an environmental threat (Roberts et al., 2017; Torrent et al., 2007), compromising the true goal of Chilean agricultural subsidy policy.

Tangentially the case study is an example of how environmental regulations can sabotage themselves by not including proper monitoring variables. Although the methodology to quantify PBuffer correspond to a local standard analysis (Sadzawka et al., 2006), there were zero entries for this variable in the INIA dataset. The P-Buffer analysis had, therefore, little impact in the risk assessment, because there were no references available to interpret the data. The direct implication is that soil P saturation was not evaluated, which is an important factor to consider when evaluating the impact of the subsidy. While monitoring soil $\mathrm{P}$ saturation is relevant for 
environmental safety (Ketterings and Czymmek, 2012; Ribey and O'Halloran, 2016; Williams et al., 2015), continuous monitoring campaigns for this variable in Chile are absent.

The Chilean regulation proposes to evaluate soil P-Olsen as an assessing tool for go/no-go subsidy decisions. However, $\mathrm{P}$-Olsen is not a measure of $\mathrm{P}$ saturation, and its transformation to a P saturation measure through pedotransfer functions cannot be trusted (Fischer et al., 2017). By this means, only a productive variable has been incorporated to the current regulation, neglecting its environmental inspiration.

The dissonance observed between regulations and requested services of $\mathrm{P}$-Buffer reveals a tangential benefit of joining field and opportunistic data. While regulations expect that land managers and owners care for the environmental status of their land establishing a formal method to address that status (P-Buffer analysis), actual laboratory requests showed an overwhelming indifference towards the proposed method. Soil monitoring per se would not point out the situation, as it will recognise $P$ saturation while neglecting the attitude of land managers.

\subsection{Usefulness of the opportunistic data analysis approach}

Reliable data are a must in science and environmental monitoring. Tidy and well-designed databases are fundamental to trustworthy results. Therefore, environmental monitoring should focus in the acquisition of high quality data. In our study, we used the conditioned Latin Hypercube Algorithm to define a sample campaign that leaved no areas unrepresented. But however solid a one-time monitoring campaign can be, it only yields a fixed value based in frequency. Therefore, prior knowledge of the area could be used to enhance the result (Bayesian interpretation of probability). Ideally, the prior knowledge should be another reliable dataset, which holds the results of previous scientific observations.

However, access to tidy and highly reliable data is not always possible. In that case, the use of third party data could be helpful to define the prior expectations for an area. In this regard, our data supported that the approach used was useful at evaluating the environmental regulation with current data availability. Nevertheless, it is evident that the need for the opportunistic approach exposes structural problems in data collection and organization, and soil testing. The INIA dataset shows how soil testing can be jeopardized when the focus is placed on the tests itself, ignoring 
locations, time and manner of sampling. The current procedure yields data that are only used for a certain client not allowing extrapolations or monitoring. If the laboratory had recorded explanatory data, the entire approach would not have been necessary. Soil samples would only have to be taken at underrepresented areas.

In this regard, the case study is an example of the problems to be faced when reliable data sources are lacking. INIA laboratory reports were not intended for data aggregation thus time and resources were designated to build the dataset. To avoid time consuming data gathering processes and to allow dynamic assessments should be the focus of data collaboration networks. In our work only one of the operating soil laboratories of Chilean central valley was included, thus bigger initiatives can be projected. Different institutions could be aligned as information contributors. It will reduce the demand for samples when monitoring, especially were resources are limited. To this goal, efforts should be focused in data structuration.

\section{Conclusions}

The opportunistic approach was useful to evaluate the application relevance of the phosphorus fertilization subsidy. The use of both datasets provided an additional insight to the regional situation. By this means, the case study provided evidence that the use of opportunistic data as supplementary information in environmental monitoring is possible and constitutes an alternative

519 for regulation assessment. Data sources are not always tidy and highly reliable, but it does not mean that they should always be discarded. As a low-cost data source, opportunistic data stand out as a convenient add-on in environmental monitoring, especially for developing economies. However, the case study exemplify how entangled the use of third party data can be when soil testing lacks of proper organization.

\section{Funding}

526 This work was supported by a conjoint effort of Dirección Regional Metropolitana of the Servicio 527 Agricola y Ganadero (Agricultural and Livestock Service, Chile); Instituto de Investigaciones Agropecuarias (INIA) [project numbers 502383-08 and 500041-70]; and CONYCIT [grant number 


\section{Acknowledgments}

532 First and foremost, we thank all the personnel that through the years has worked in La Platina Soil and Plant Nutrition Laboratory. Also, we sincerely thank the Comité Técnico Regional para la

Sustentabilidad Ambiental de los Suelos Degradados (RM), specially to Ivone Aranguiz from

535 Secretaría Ministerial de Agricultura, and Pilar Toledo from Instituto de Desarrollo Agropecuario.

536 Special thanks to all members of the Servicio Agrícola y Ganadero and Instituto de Investigaciones 537 Agropecuarias that contribute with the sampling campaign that made this work possible. We also 538 thank Selamawit Amare, Coleen Carranza, Mirzokhid Mirshadiev, Demie Moore, Ricardo Teixeira 539 da Silva, Yan Wang, and Miao Yu, for proofreading the manuscript.

\section{References}

542 Abbott, B.W., Moatar, F., Gauthier, O., Fovet, O., Antoine, V., Ragueneau, O., 2018. Trends and seasonality of river nutrients in agricultural catchments: 18years of weekly citizen science in France. Science of The Total Environment 624, 845-858. https://doi.org/10.1016/j.scitotenv.2017.12.176

Allen, B.L., Mallarino, A.P., 2006. Relationships between extractable soil phosphorus and phosphorus saturation after long-term fertilizer or manure application. Soil Science Society

Barrett, C.B., Bevis, L.E.M., 2015. The self-reinforcing feedback between low soil fertility and 553 chronic poverty. Nature Geoscience 8(12), 907-912. https://doi.org/10.1038/ngeo2591 of America Journal 70(2), 454-463. https://doi.org/10.2136/sssaj2005.0031

Auerswald, K., Fischer, F.K., Kistler, M., Treisch, M., Maier, H., Brandhuber, R., 2018. Behavior of farmers in regard to erosion by water as reflected by their farming practices. Science of The Total Environment 613-614, 1-9. https://doi.org/10.1016/j.scitotenv.2017.09.003

Caro, J.C., Melo, O., Foster, W., 2006. Participación e Impacto del Programa de Recuperación de Suelos Degradados en Usuarios de INDAP. Economía Agrária 10, 11-24. 
Casanova, M., Salazar, O., Seguel, O., Luzio, W., 2013. The Soils of Chile. World Soils Book Series Springer, Dordrecht, Netherlands. https://doi.org/10.1007/978-94-007-5949-7

CIREN, 1996. Estudio agrológico Región Metropolitana. Publicación CIREN 115. Centro de Información de Recursos Naturales (CIREN), Santiago, Chile.

CONAF, CIREN, 2013. Monitoreo de cambios, corrección cartográfica y actualización del catastro de los recursos vegetacionales nativos de las regiones de Valparaíso, Metropolitana y Libertador Bernardo O’Higgins. Informe Técnico Final. Corporación Nacional Forestal (CONAF), Centro de Información de Recursos Naturales (CIREN), Santiago, Chile.

Cowles, M.K., 2013. Applied Bayesian Statistics. Springer Texts in Statistics. Springer, New York, NY. https://doi.org/10.1007/978-1-4614-5696-4

Daly, K., Styles, D., Lalor, S., Wall, D.P., 2015. Phosphorus sorption, supply potential and availability in soils with contrasting parent material and soil chemical properties. European Journal of Soil Science 66(4), 792-801. https://doi.org/10.1111/ejss.12260

Diner, D., Nakayama, S., Nov, O., Porfiri, M., 2018. Social signals as design interventions for enhancing citizen science contributions. Information, Communication \& Society 21(4), 594611. https://doi.org/10.1080/1369118X.2017.1299779

Dirección Meteorológica de Chile, 2010-2016. Anuarios climatológicos. Dirección General de Aeronáutica Civil, Dirección Meteorologica de Chile, Subdepartamento Climatología y Meteorología Aplicada., Santiago, Chile.

Dupas, R., Delmas, M., Dorioz, J.M., Garnier, J., Moatar, F., Gascuel-Odoux, C., 2015. Assessing the impact of agricultural pressures on $\mathrm{N}$ and $\mathrm{P}$ loads and eutrophication risk. Ecological Indicators 48, 396-407. https://doi.org/10.1016/j.ecolind.2014.08.007

Fischer, P., Pöthig, R., Venohr, M., 2017. The degree of phosphorus saturation of agricultural soils in Germany: Current and future risk of diffuse $P$ loss and implications for soil $P$ management in Europe. Science of the Total Environment 599-600, 1130-1139. https://doi.org/10.1016/j.scitotenv.2017.03.143

Fiszbein, A., Kanbur, R., Yemtsov, R., 2014. Social Protection and Poverty Reduction: Global Patterns and Some Targets. World Development 61, 167-177. https://doi.org/10.1016/j.worlddev.2014.04.010 
Floress, K., Reimer, A., Thompson, A., Burbach, M., Knutson, C., Prokopy, L., Ribaudo, M., UlrichSchad, J., 2018. Measuring farmer conservation behaviors: Challenges and best practices. Land Use Policy 70, 414-418. https://doi.org/10.1016/j.landusepol.2017.11.030

Gelman, A., Carlin, J.B., Stern, H.S., Dunson, D.B., Vehtari, A., Rubin, D.B., 2013. Bayesian Data Analysis. Chapman \& Hall/CRC Texts in Statistical Science. Third Edition ed. CRC Press, Boca Raton, FL.

Giraud, C., Calenge, C., Coron, C., Julliard, R., 2016. Capitalizing on opportunistic data for monitoring relative abundances of species. Biom 72(2), 649-658. https://doi.org/10.1111/biom.12431

Hijmans, R.J., 2017. raster: Geographic Data Analysis and Modeling. R package version 2.6-7. Holden, S.T., Lunduka, R.W., 2014. Input subsidies, cash constraints, and timing of input supply. American Journal of Agricultural Economics 96(1), 290-307. https://doi.org/10.1093/ajae/aat059

Kelepertzis, E., 2014. Accumulation of heavy metals in agricultural soils of Mediterranean: Insights from Argolida basin, Peloponnese, Greece. Geoderma 221-222(Supplement C), 82-90. https://doi.org/10.1016/j.geoderma.2014.01.007

Ketterings, Q.M., Czymmek, K.J., 2012. Phosphorus index as a phosphorus awareness tool: Documented phosphorus use reduction in New York state. Journal of Environmental Quality 41(6), 1767-1773. https://doi.org/10.2134/jeq2012.0050

Koppmair, S., Kassie, M., Qaim, M., 2017. The influence of farm input subsidies on the adoption of natural resource management technologies. Australian Journal of Agricultural and Resource Economics 61(4), 539-556. https://doi.org/10.1111/1467-8489.12220

Kottek, M., Grieser, J., Beck, C., Rudolf, B., Rubel, F., 2006. World Map of the Köppen-Geiger climate classification updated. Meteorologische Zeitschrift 15(3), 259-263. https://doi.org/10.1127/0941-2948/2006/0130

Krueger, T., 2017. Bayesian inference of uncertainty in freshwater quality caused by low-resolution monitoring. Water Research 115, 138-148. https://doi.org/10.1016/j.watres.2017.02.061 
Lima, L.S.d., Krueger, T., García-Marquez, J., 2017. Uncertainties in demonstrating environmental benefits of payments for ecosystem services. Ecosystem Services 27, 139-149. https://doi.org/10.1016/j.ecoser.2017.09.005

Lots, F.A.E., Behrens, P., Vijver, M.G., Horton, A.A., Bosker, T., 2017. A large-scale investigation of microplastic contamination: Abundance and characteristics of microplastics in European beach sediment. Marine Pollution Bulletin 123(1), 219-226. https://doi.org/10.1016/j.marpolbul.2017.08.057

Lowder, S.K., Bertini, R., Croppenstedt, A., 2017. Poverty, social protection and agriculture: Levels and trends in data. Global Food Security 15, 94-107. https://doi.org/10.1016/j.gfs.2017.06.001

Mason, N.M., Jayne, T.S., 2013. Fertiliser subsidies and smallholder commercial fertiliser purchases: Crowding out, leakage and policy implications for Zambia. Journal of Agricultural Economics 64(3), 558-582. https://doi.org/10.1111/1477-9552.12025

Mason, N.M., Jayne, T.S., Mofya-Mukuka, R., 2013. Zambia's input subsidy programs. Agricultural Economics 44(6), 613-628. https://doi.org/10.1111/agec.12077

Minasny, B., McBratney, A.B., 2006. A conditioned Latin hypercube method for sampling in the presence of ancillary information. Computers \& Geosciences 32(9), 1378-1388. https://doi.org/10.1016/j.cageo.2005.12.009

Ministerio de Agricultura, 1999. Decreto con fuerza de ley 235. Establece sistema de incentivos para la recuperacion de suelos degradados. Gobierno de Chile.

Ministerio de Agricultura, 2010. Ley número 20.412. Establece un sistema de incentivos para la sustentabilidad agroambiental de los suelos agropecuarios. Gobierno de Chile.

Ministerio de Agricultura, 2015. Decreto 51. Fija reglamento de la ley N 20.412 que establece un sistema de incentivos para la sustentabilidad agroambiental de los suelos agropecuarios. Gobierno de Chile.

Nyssen, J., Biruk, B., Tesfamariam, Z., Frankl, A., Demissie, B., Ghebreyohannes, T., Meaza, H., Poesen, J., Van Eetvelde, V., Zenebe, A., Deckers, J., Haile, M., 2017. Geographical determinants of inorganic fertiliser sales and of resale prices in north Ethiopia. Agriculture, Ecosystems \& Environment 249, 256-268. https://doi.org/10.1016/j.agee.2017.07.037 
Olsen, S.R., Cole, C.V., Watanabe, F.S., 1954. Estimation of available phosphorus in soils by extraction with sodium bicarbonate. Circular / United States Department of Agriculture;no. 939. USDA, Washington.

QGIS Development Team, 2017. QGIS Geographic Information System. Open Source Geospatial Foundation Project.

R Core Team, 2017. R: A Language and Environment for Statistical Computing. R Foundation for Statistical Computing, Vienna, Austria.

Ribey, M.A., O'Halloran, I.P., 2016. Consequences of Ontario P index recommendations for reduced manure and fertilizer phosphorus applications on corn yields and soil phosphorus. Canadian Journal of Soil Science 96(2), 191-198. https://doi.org/10.1139/cjss-2015-0072

Ricker-Gilbert, J., Jayne, T.S., 2017. Estimating the Enduring Effects of Fertiliser Subsidies on Commercial Fertiliser Demand and Maize Production: Panel Data Evidence from Malawi. Journal of Agricultural Economics 68(1), 70-97. https://doi.org/10.1111/1477-9552.12161

Roberts, W.M., Gonzalez-Jimenez, J.L., Doody, D.G., Jordan, P., Daly, K., 2017. Assessing the risk of phosphorus transfer to high ecological status rivers: Integration of nutrient management with soil geochemical and hydrological conditions. Science of the Total Environment 589, 25-35. 10. https://doi.org/1016/j.scitotenv.2017.02.201

Roudier, P., 2017. clhs: a R package for conditioned Latin hypercube sampling. R package version $0.5-7$.

Roudier, P., Hewitt, A.E., Beaudette, D.E., 2012. A conditioned Latin hypercube sampling algorithm incorporating operational constraints. In: B. Minasny, B.P. Malone, A.B. McBratney (Eds.), Digital Soil Assessments and Beyond. CRC Press, London, UK.

Sadzawka, A., Carrasco, M.A., Grez, R., Mora, M.d.I.L., Flores, H., Neaman, A., 2006. Métodos de análisis de suelos recomendados para los suelos de Chile. Revisión 2006. Serie Actas INIA № 34. Instituto de Investigaciones Agropecuarias, Santiago, Chile.

Silvertown, J., 2009. A new dawn for citizen science. Trends in Ecology \& Evolution 24(9), 467471. https://doi.org/10.1016/j.tree.2009.03.017

Sullivan, T.J., Driscoll, C.T., Beier, C.M., Burtraw, D., Fernandez, I.J., Galloway, J.N., Gay, D.A., Goodale, C.L., Likens, G.E., Lovett, G.M., Watmough, S.A., 2018. Air pollution success 

stories in the United States: The value of long-term observations. Environmental Science and Policy 84, 69-73. https://doi.org/10.1016/j.envsci.2018.02.016

Tarfasa, S., Balana, B.B., Tefera, T., Woldeamanuel, T., Moges, A., Dinato, M., Black, H., 2018. Modeling Smallholder Farmers' Preferences for Soil Management Measures: A Case Study From South Ethiopia. Ecological Economics 145, 410-419. https://doi.org/10.1016/j.ecolecon.2017.11.027

The National Aeronautics and Space Administration, N., Ministry of Economy Trade and Industry, M., 2011. The Advanced Spaceborne Thermal Emission and Reflection Radiometer (ASTER) Global Digital Elevation Model (GDEM). Version 2. ASTER GDEM is a product of NASA and METI.

Tirivayi, N., Knowles, M., Davis, B., 2016. The interaction between social protection and agriculture: A review of evidence. Global Food Security 10, 52-62. https://doi.org/10.1016/j.gfs.2016.08.004

Torrent, J., Barberis, E., Gil-Sotres, F., 2007. Agriculture as a source of phosphorus for eutrophication in southern Europe. Soil Use and Management 23(SUPPL. 1), 25-35. https://doi.org/10.1111/j.1475-2743.2007.00122.x

Tulloch, A.I.T., Possingham, H.P., Joseph, L.N., Szabo, J., Martin, T.G., 2013. Realising the full potential of citizen science monitoring programs. Biological Conservation 165, 128-138. https://doi.org/10.1016/j.biocon.2013.05.025

Venables, W., Ripley, B., 2002. Modern Applied Statistics with S. Fourth ed. Springer, New York. https://doi.org/10.1007/978-0-387-21706-2

Watson, C.J., Smith, R.V., Matthews, D.I., 2007. Increase in phosphorus losses from grassland in response to Olsen-P accumulation. Journal of Environmental Quality 36(5), 1452-1460. https://doi.org/10.2134/jeq2006.0207

Williams, M.R., King, K.W., Dayton, E., Labarge, G.A., 2015. Sensitivity analysis of the ohio phosphorus risk index. Transactions of the ASABE 58(1), 93-102. https://doi.org/10.13031/trans.58.10778 
Yu, B., Fan, S., Magalhães, E., 2015. Trends and Composition of Public Expenditures: A Global and Regional Perspective. The European Journal of Development Research 27(3), 353370. https://doi.org/10.1057/ejdr.2015.26

\section{Figure Captions}

Figure 1. Interactive Map: Chilean Metropolitana Region. Soils comprehended in the study area are marked with light red polygons that include soil order, suborder, great group, and subgroup. Sampling points are indicated, each holding information of land use, P-Olsen, and P-Buffer.

Figure 2. Histogram of scaled and log-transformed (In) P-Olsen values in the INIA dataset (a) and the soil monitoring dataset (b). The density of the normal distribution $\mathrm{N}\left(\mu=0, \sigma^{2}=1\right)$ is included in red.

Figure 3. Histogram of bootstrapped values for the mean $(\mu)(a)$ and precision (т) (b) of logtransformed P-Olsen values in INIA dataset. the normal distribution function $\mathrm{N}\left(\mu=0, \sigma^{2}=1\right)$ is proposed as a theoretical approximation for $\mu$, and the gamma distribution $\mathrm{Ga}(\alpha=29, \beta=46)$ for $\mathrm{T}$.

Figure 4. Empirical cumulative density function for expected P-Buffer values.

Figure 5. Spatial distribution for P-Olsen concentrations. North-south and west-east transects regarding soil P-Olsen concentration are included. Block means every $3 \mathrm{~km}$ are shown by a black line.

Figure 6. Average cumulative distribution function estimated for P-Olsen within the study area (solid line), including a 95\% confidence interval (dotted line). 


\begin{tabular}{|c|c|}
\hline Program clusters & Conservation/restoration practice \\
\hline Application of phosphate fertilizers & Phosphate fertilizers \\
\hline $\begin{array}{l}\text { Application of essential chemical } \\
\text { elements }\end{array}$ & $\begin{array}{l}\text { Liming } \\
\text { Potassium fertilizers } \\
\text { Sulfur fertilizers }\end{array}$ \\
\hline $\begin{array}{l}\text { Establishment of a vegetative cover } \\
\text { on bare soils or with deteriorated } \\
\text { cover }\end{array}$ & Sowing or maintenance of grasslands \\
\hline Use of soil conservation practices & $\begin{array}{l}\text { Compost } \\
\text { Chicken manure } \\
\text { Other manures } \\
\text { Guano } \\
\text { Phosphate rock } \\
\text { No-till sowing } \\
\text { Drinking troughs } \\
\text { Diversion channels } \\
\text { Barbed wire fence } \\
\text { Ursus mesh fence } \\
\text { Electric fence } \\
\text { Countour stone bunds } \\
\text { Bench terraces } \\
\text { Negarim microcatchments } \\
\text { Semi-circular bunds } \\
\text { Water spreading bunds } \\
\text { Green manure } \\
\text { Incorporation of volcanic ashes and oat cultivation (after eruption) } \\
\text { Land levelling } \\
\text { Use of chisel plow } \\
\text { Use of subsoiler }\end{array}$ \\
\hline $\begin{array}{l}\text { Remotion, cleaning or confinement } \\
\text { of physical or chemical } \\
\text { impediments }\end{array}$ & $\begin{array}{l}\text { Scrub removal } \\
\text { Ulex europaeus L. removal } \\
\text { Stone removal }\end{array}$ \\
\hline $\begin{array}{l}\text { Use of soil conservation practices } \\
\text { [whole country] }\end{array}$ & $\begin{array}{l}\text { Narrow buffer strips } \\
\text { No-till stubble reduction } \\
\text { No-till herbicide application } \\
\text { Gully control } \\
\text { Windbreaks } \\
\text { Agroforestry } \\
\text { Exclosure (no grazing) } \\
\text { Adjust livestock numbers } \\
\text { Stubble management } \\
\text { Nitrification inhibitors } \\
\text { Crop rotation }\end{array}$ \\
\hline
\end{tabular}

Note: The provided information is an independent transcription of the official document (Ministerio de Agricultura, 2015) available at Note: For a definition of each practice, the supplementary decree of the previous one is available at [Spanish] $\langle\mathrm{http}: / / \mathrm{bcn} . \mathrm{cl} / 28 \mathrm{c} 5 \mathrm{p}\rangle$ 
[Spanish] <http://bcn.cl/1vg4w> 


\begin{tabular}{|c|c|c|c|c|c|c|}
\hline \multirow[t]{2}{*}{ Order } & \multirow[t]{2}{*}{ Suborder } & \multirow[t]{2}{*}{ Greatgroup } & \multirow[t]{2}{*}{ Subgroup } & \multirow{2}{*}{$\begin{array}{c}\text { Area } \\
\text { ha } \\
\end{array}$} & \multirow{2}{*}{$\frac{\text { Samples }}{\mathrm{n}}$} & \multirow{2}{*}{$\frac{\text { Area : Samples }}{\mathrm{ha} / \mathrm{h}}$} \\
\hline & & & & & & \\
\hline Alfisol & Xeralfs & Durixeralfs & Abruptic Durixeralfs & 874 & 1 & 874 \\
\hline Alfisol & Xeralfs & Haploxeralfs & Mollic Haploxeralfs & 3722 & 7 & 532 \\
\hline Alfisol & Xeralfs & Haploxeralfs & Ultic Haploxeralfs & 20490 & 19 & 1078 \\
\hline Entisol & Aquents & Fluvaquents & Aeric Fluvaquents & 1335 & 2 & 668 \\
\hline Entisol & Orthents & Xerorthents & Typic Xerorthents & 3516 & 9 & 391 \\
\hline Inceptisol & Aquepts & Epiaquepts & Mollic Epiaquepts & 2077 & 3 & 692 \\
\hline Inceptisol & Xerepts & Haploxerepts & Fluventic Xerochrept & 2413 & 7 & 345 \\
\hline Inceptisol & Xerepts & Haploxerepts & Typic Xerochrepts & 24183 & 45 & 537 \\
\hline Mollisol & Aquolls & Calciaquolls & Petrocalcic Calciaqu & 5436 & 10 & 544 \\
\hline Mollisol & Aquolls & Calciaquolls & Typic Calciaquolls & 4469 & 9 & 497 \\
\hline Mollisol & Aquolls & Epiaquolls & Fluvaquentic Epiaquo & 2839 & 3 & 946 \\
\hline Mollisol & Xerolls & Argixerolls & Typic Argixerolls & 6319 & 9 & 702 \\
\hline Mollisol & Xerolls & Calcixerolls & Vertic Calcixerolls & 2460 & 4 & 615 \\
\hline Mollisol & Xerolls & Durixerolls & Vitradic Durixerolls & 18086 & 31 & 583 \\
\hline Mollisol & Xerolls & Haploxerolls & Calcic Haploxerolls & 1574 & 2 & 787 \\
\hline Mollisol & Xerolls & Haploxerolls & Duric Haploxerolls & 383 & 2 & 192 \\
\hline Mollisol & Xerolls & Haploxerolls & Entic Haploxerolls & 18446 & 36 & 512 \\
\hline Mollisol & Xerolls & Haploxerolls & Fluventic Haploxerol & 40823 & 77 & 530 \\
\hline Mollisol & Xerolls & Haploxerolls & Lithic Haploxerolls & 1850 & 2 & 925 \\
\hline Mollisol & Xerolls & Haploxerolls & Pachic Haploxerolls & 1139 & 4 & 285 \\
\hline Mollisol & Xerolls & Haploxerolls & Typic Haploxerolls & 21234 & 50 & 425 \\
\hline Mollisol & Xerolls & Haploxerolls & Ultic Haploxerolls & 20290 & 39 & 520 \\
\hline Mollisol & Xerolls & Haploxerolls & Vertic Haploxerolls & 8120 & 16 & 508 \\
\hline Mollisol & Xerolls & Palexerolls & Haplic Palexerolls & 1171 & 3 & 390 \\
\hline Mollisol & Xerolls & Palexerolls & Petrocalcic Palexero & 2250 & 3 & 750 \\
\hline Mollisol & Xerolls & Palexerolls & Vertic Palexerolls & 2107 & 6 & 351 \\
\hline Vertisol & Aquerts & Epiaquerts & Halic Epiaquerts & 1062 & 1 & 1062 \\
\hline Vertisol & Xererts & Haploxerts & Sodic Haploxererts & 4078 & 7 & 583 \\
\hline Vertisol & Xererts & Haploxerts & Typic Haploxererts & 4590 & 6 & 765 \\
\hline \multicolumn{4}{|c|}{ Recent terraces or unconsolidated sediments } & - & 71 & - \\
\hline \multicolumn{4}{|l|}{ Total } & 227336 & 484 & \\
\hline
\end{tabular}




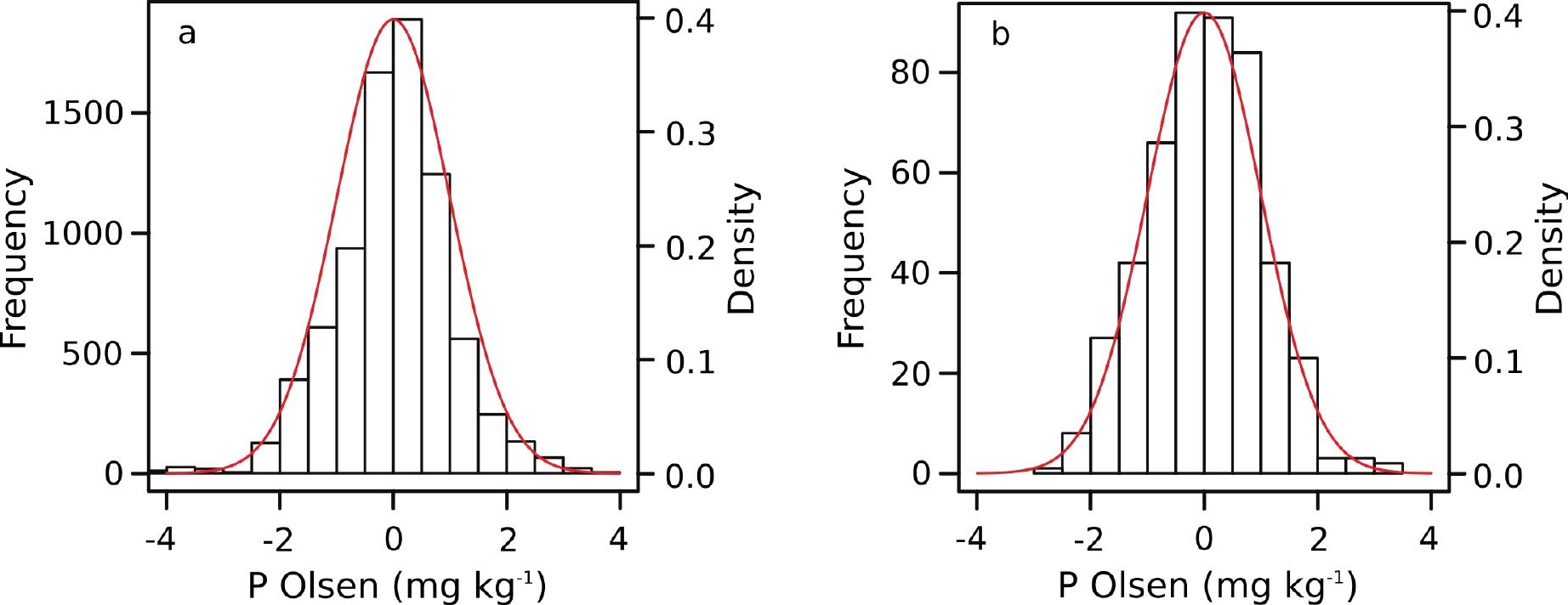




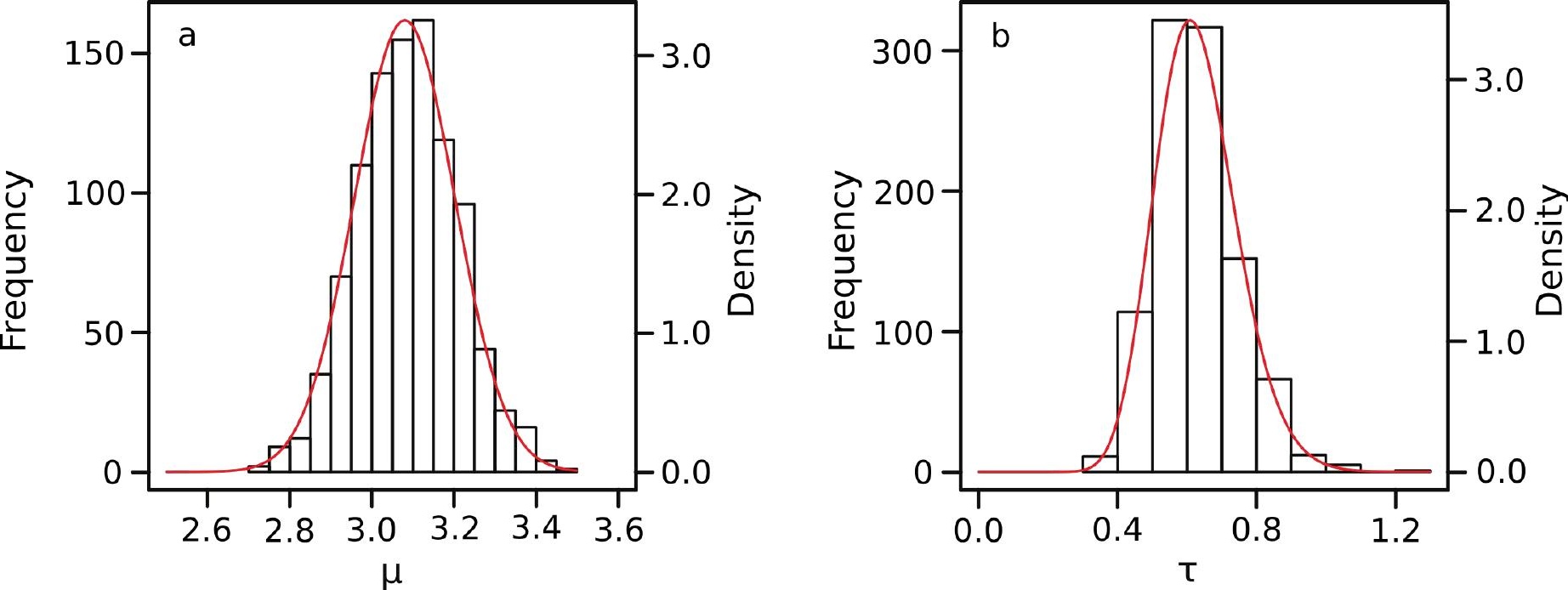




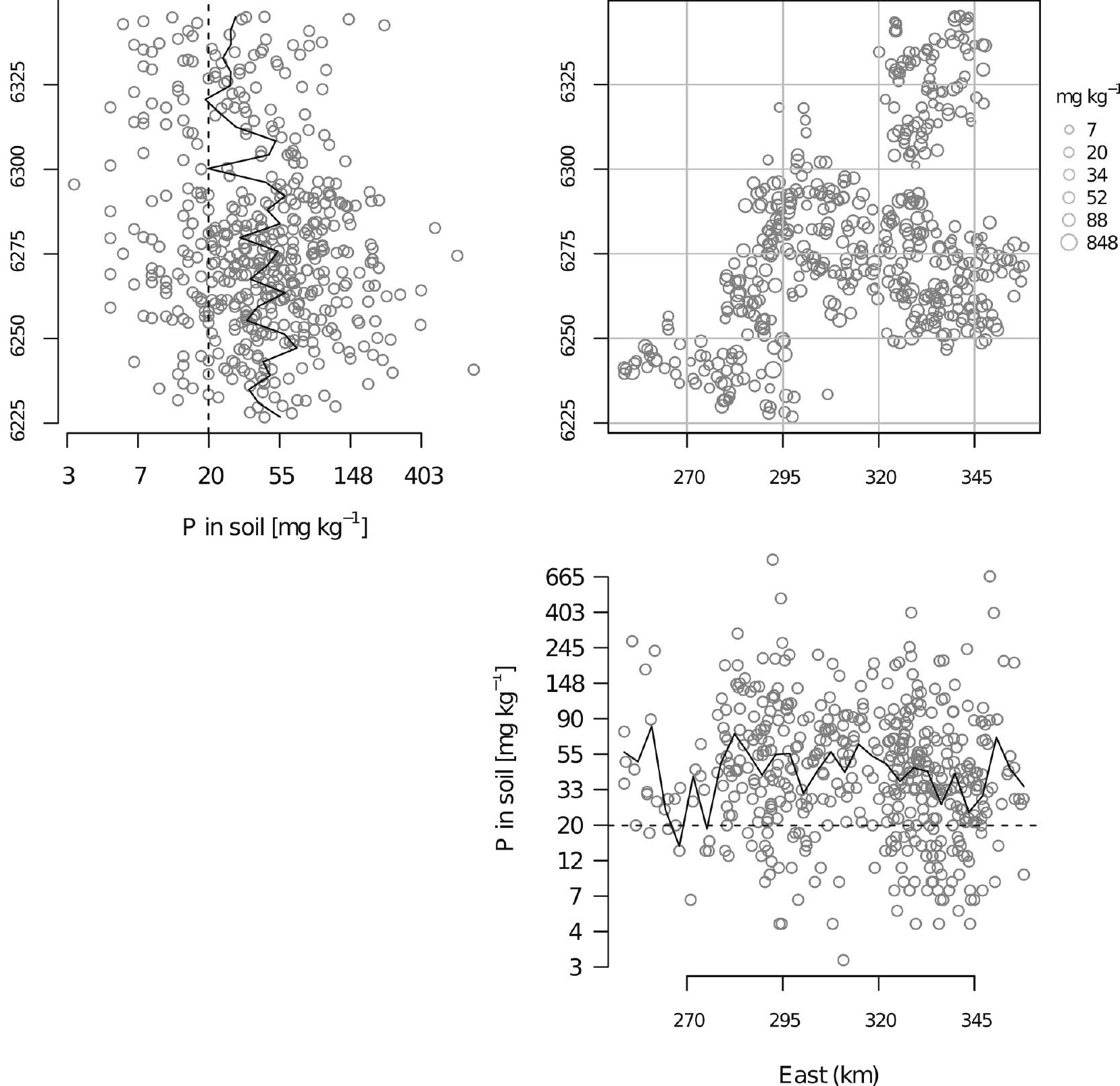




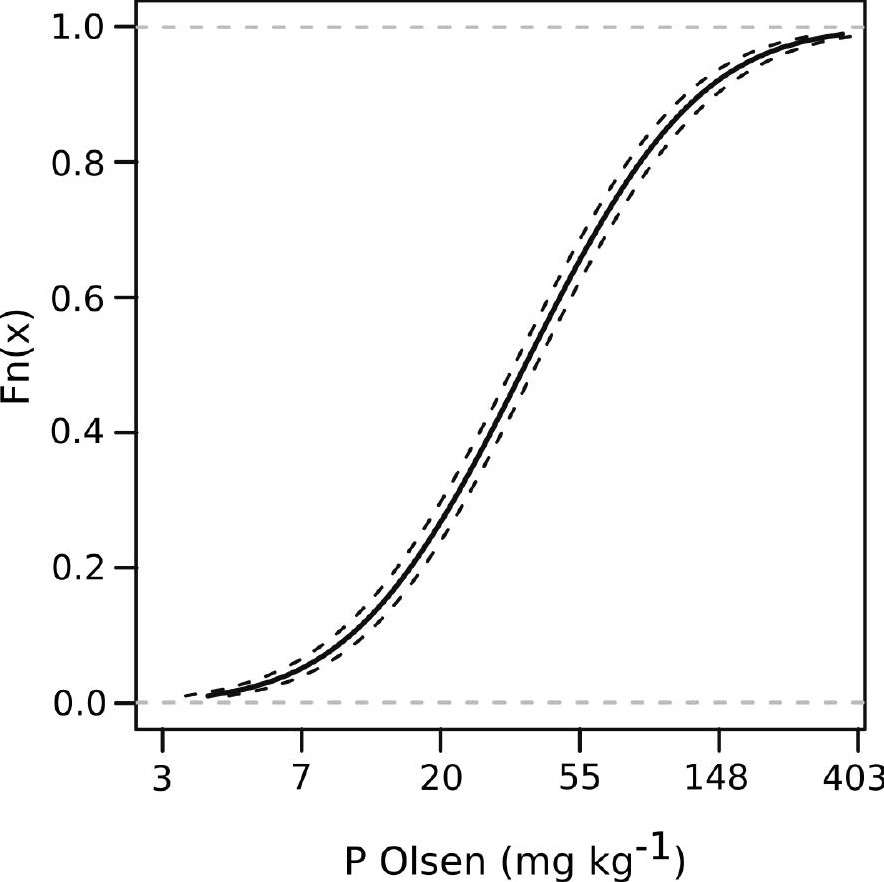

